\title{
Homology of Plasmids in Strains of Unicellular Cyanobacteria
}

\author{
C. A. M. J. J. van den Hondel, ${ }^{*}$ W. Keegstra, $†$ W. E. Borrias, ${ }^{*}$ \\ AND G. A. VAN ARKEL* \\ *Department of Molecular Cell Biology and †Institute of Molecular Biology, State University of \\ Utrecht, Utrecht, The Netherlands
}

Received July 24, 1978

\begin{abstract}
Six strains of unicellular cyanobacteria were examined for the presence of plasmids. Analysis of lysates of these strains by $\mathrm{CsCl}$-ethidium bromide density centrifugation yielded a major chromosomal DNA band and a minor band containing covalently closed circular plasmid DNA, as shown by electron microscopy and agarose gel electrophoresis. The sizes of the various plasmid species were determined; in each of the Synechococcus strains 6301,6707 , and 6908 two plasmid species were found with molecular weights of $5.3 \times 10^{6}$ and $32.7 \times 10^{6}$. Synechococcus strain 7425 had two plasmids of molecular weight $5.4 \times 10^{6}$ and $24 \times 10^{6}$. Synechococcus strain 6312 and Synechocystis strain 7005 each contained one plasmid species with molecular weight of $15.9 \times 10^{6}$ and $2.0 \times 10^{6}$, respectively. Restriction enzyme analysis revealed identical cleavage patterns for the plasmids of identical molecular weight.
\end{abstract}

The cyanobacteria, traditionally known as the blue-green algae, are photoautotrophic organisms with a number of interesting properties which make them very attractive for molecular biological studies (for reviews, see Carr and Whitton, 1973; Fogg et al., 1973; Stanier et al., 1971; Wolk, 1973). For instance, the cyanobacteria are the only prokaryotic organisms in which an oxygenic type of photosynthesis very similar to that in plants is present (Stanier, 1977). In addition, their molecular mechanism of oxidative metabolism is interesting because of the similarity with that of the mitochondria of eukaryotic cells (Dickerson et al., 1976). Furthermore, some of the cyanobacteria are able to fix nitrogen, a process which is of increasing scientific and agricultural interest (Stewart, 1969; Rippka et al., 1971; Fogg et al., 1973). However, the molecular biology of these processes is still poorly understood.

Little is known about the properties and organization of the DNA of the cyanobacteria, although recently a few studies have been published on the chromosomal DNA of some unicellular cyanobacteria (Herdmann, 1976; Herdmann and Carr, 1974; Mann and Carr, 1974; Roberts et al., 1977). Of particular interest is the observation that some unicellular cyanobacteria contain extrachromosomal (plasmid) DNA (Asato and Ginoza, 1973; Restaino and Frampton, 1975; Roberts and Koths, 1976). Plasmids have proven extremely useful in the genetic analysis of various bacteria. Therefore we were encouraged to analyze a number of unicellular cyanobacteria for the presence of plasmids.

In this paper we present evidence for the presence of covalently closed circular (CCC) plasmid DNA in six strains of unicellular cyanobacteria, Synechococcus 6301, S.6312, S.6707, S.6908, S.7425 and Synechocystis 7005. The sizes and molecular weights of the various plasmids present in these strains were determined by agarose gel electrophoresis and electron microscopy. Digestion of the two plasmid species of Synechococcus $6301, S .6707$, and $S .6908$ with different re- 
striction enzymes showed identical cleavage patterns on both agarose and polyacrylamide gels.

We have developed a fast screening method for determining the number of plasmid species in the plasmid band of $\mathrm{CsCl}-$ ethidium bromide gradients. The method involves comparing heat-treated samples to unheated samples on agarose gels.

\section{MATERIALS AND METHODS}

Cyanobacterial strains. The cyanobacterial strains used were obtained from the collection of Dr. R. Y. Stanier at the Pasteur Institute, Paris. Strains 6301, 6312, 6707, 6908,7002 , and 7425 are unicellular cyanobacteria assigned to the typological group Synechococcus (R. Rippka, personal communication). Strain Anacystis nidulans 0100 , obtained from Dr. N. G. Carr, Liverpool, and strain Anacystis nidulans IU625, obtained from Dr. R. Safferman, Cincinnati, which were also analyzed during this study, differ in no way from strain 6301 and are therefore referred to as 6301; strain Synechococcus cedrorum IU1911 (obtained from Dr. R. Safferman, Cincinnati) is identical to strain 6908 and is referred to as 6908 (Stanier et al., 1971). Strain 7005 is a unicellular cyanobacterium assigned to the typological group Synechocystis (R. Rippka, personal communication) and classified as Microcystis aeruginosa (Stanier et al., 1971). Strain 7002, also known as Agmenellum quadruplicatum strain PR6 (Stanier et al., 1971), was used for the isolation of marker plasmids, since during the progress of the present study it was shown that this strain contains plasmids of six different molecular weights (Roberts and Koths, 1976).

Media and buffers. Cells were grown in BG11 medium (Stanier et al., 1971), except those of strain 7002 which were grown in ASN III medium supplemented with $0.1 \mu \mathrm{g} /$ $\mathrm{ml}$ vitamin B12 (R. Rippka, personal communication). ASN III medium contains per liter: $\mathrm{NaCl}, 25 \mathrm{~g} ; \mathrm{MgSO}_{4} \cdot 7 \mathrm{H}_{2} \mathrm{O}, 3.5 \mathrm{~g}$; $\mathrm{MgCl}_{2} \cdot 6 \mathrm{H}_{2} \mathrm{O}, 2 \mathrm{~g} ; \mathrm{KCl}, 0.5 \mathrm{~g} ; \mathrm{CaCl}_{2} \cdot 2 \mathrm{H}_{2} \mathrm{O}$,
$0.5 \mathrm{~g}$; citric acid, $0.003 \mathrm{~g}$; ferric ammonium citrate, $0.003 \mathrm{~g}$; EDTA, $0.0005 \mathrm{~g} ; \mathrm{K}_{2} \mathrm{HPO}_{4}$. $3 \mathrm{H}_{2} \mathrm{O}, 0.029 \mathrm{~g} ; \mathrm{Na}_{2} \mathrm{CO}_{3}, 0.02 \mathrm{~g} ; \mathrm{NaNO}_{3}$, $0.75 \mathrm{~g}$, and $1 \mathrm{ml}$ of the trace metal mix of BG11 medium. The medium was sterilized $20 \mathrm{~min}$ at $121^{\circ} \mathrm{C}$. SE buffer contains $0.12 \mathrm{M}$ $\mathrm{NaCl}$ and $0.05 \mathrm{M}$ EDTA, pH 8.0, TE buffer contains $0.01 \mathrm{M}$ tris(hydroxymethyl)aminomethane and $0.001 \mathrm{M}$ EDTA, pH 7.6, and lysis buffer contains $25 \%$ sucrose, $0.05 \mathrm{M}$ tris(hydroxymethyl)aminomethane, and 0.1 M EDTA, pH 8.0.

Culture conditions. Stock cultures were grown in $50 \mathrm{ml}$ of the appropriate medium in 250-ml Erlenmeyer flasks in a light cabinet at a temperature of $26-28^{\circ} \mathrm{C}$. Cultures of large volume (4 liter) were grown in 5-liter Erlenmeyer flasks equipped with magnetic stirrers and incubated in water baths provided with lateral illumination from banks of two white fluorescent tubes. The light intensity was in the range of 4000 to 6000 lux at the surface of the Erlenmeyer flask. The 4liter cultures were gassed with $\mathrm{N}_{2}$ containing $5 \%(\mathrm{v} / \mathrm{v}) \mathrm{CO}_{2}$. They were inoculated with $5-10 \mathrm{ml}$ of liquid stock cultures of cells in exponential growth phase (for the strains 7005 and 7425 , that show very long lag times) or late-exponential growth phase (for all other strains). The following growth temperatures proved to be optimal: $37^{\circ} \mathrm{C}$ for the strains $6301,6707,6908$, and $7002,34^{\circ} \mathrm{C}$ for strains 6312 and 7425 , and $30^{\circ} \mathrm{C}$ for strain 7005. Under these conditions the doubling time during exponential growth was $5 \pm 1 \mathrm{~h}$ for 6301,6707 , and $6908,14 \pm 2$ h for 6312 , 7005 , and 7425 , and $9 \pm 1 \mathrm{~h}$ for 7002 . The density of the cultures at the end of the exponential phase, when the cells were harvested for plasmid isolation, was 2-4 $\times 10^{8} \mathrm{cells} / \mathrm{ml}$ for $6301,6707,6908$, and $7002,1-2 \times 10^{8}$ cells $/ \mathrm{ml}$ for 6312 , and $2-5 \times 10^{7}$ cells for 7005 and 7425 .

Isolation of plasmid DNA. The cells of a 4-liter culture were harvested by centrifugation, washed once in SE buffer, resuspended in $68 \mathrm{ml}$ lysis buffer, and transferred into four Beckman R30 tubes ( $17 \mathrm{ml}$ in each tube). After incubating the cells with lysozyme 
(final concentration $2 \mathrm{mg} / \mathrm{ml}$ ) for $1 \mathrm{~h}$ at $37^{\circ} \mathrm{C}$, a clear lysate was prepared by a modification of the method described by Guerry et al. (1973): to each of the four R30 tubes $3 \mathrm{ml}$ of $10 \%$ sodium dodecyl sulfate (SDS) was added and mixed carefully, and the $20-\mathrm{ml}$ mixture was incubated for $1 \mathrm{~h}$ at $37^{\circ} \mathrm{C}$. Then $5 \mathrm{ml}$ of $5 \mathrm{M} \mathrm{NaCl}$ was added gently and mixed, and the tubes were kept in ice for $2 \mathrm{~h}$. Most of the chromosomal DNA was removed by centrifugation at $25,000 \mathrm{rpm}$ for $30 \mathrm{~min}$ at $4^{\circ} \mathrm{C}$ in a Beckman type 30 rotor. (Occasionally SDS was substituted by Sarkosyl or Brij; this yielded the same number of plasmid species.) The supernatant (clear lysate) of each R30 tube was concentrated by polyethylene glycol (PEG) precipitation (Humphreys et al., 1975) to $7.15 \mathrm{ml}$. This concentrated clear lysate was transferred into a cellulose nitrate tube (Beckman 50Ti) and incubated with RNase $(0.05 \mathrm{ml}$ of 10 $\mathrm{mg} / \mathrm{ml}$, heated for $10 \mathrm{~min}$ at $80^{\circ} \mathrm{C}$ ) for 30 min at $37^{\circ} \mathrm{C}$. $\mathrm{CsCl}$ and $0.8 \mathrm{ml}$ ethidium bromide $(5 \mathrm{mg} / \mathrm{ml})$ were added, the $\mathrm{CsCl}$ was dissolved carefully, and the solution was centrifuged at 37,500 rpm for $60 \mathrm{~h}$ at $15^{\circ} \mathrm{C}$. $7.8 \mathrm{~g} \mathrm{CsCl}$ was added in the case of strains 6301, 6312, 6908, and 7002, $7.7 \mathrm{~g}$ $\mathrm{CsCl}$ in the case of strain $7425,8.1 \mathrm{~g} \mathrm{CsCl}$ in the case of strain 6707 , and $7.6 \mathrm{CsCl}$ in the case of strain 7005 . After centrifugation the gradients were screened with ultraviolet light and the plasmid and chromosomal DNA bands were collected by puncturing the bottom of the tube. The DNA was precipitated with ethanol, dissolved in TE buffer, and analyzed by electron microscopy and agarose gel electrophoresis. For electron microscopic analysis the ethanol precipitation was preceded by an isoamyl alcohol extraction $(3 \times)$.

In those cases where the different plasmid species of one host strain were separated, the $\mathrm{CsCl}$-ethidium bromide plasmid fraction was sedimented through a $10-30 \%$ sucrose gradient in $0.1 \mathrm{M} \mathrm{NaCl}, 10 \mathrm{~mm}$ Tris $-\mathrm{HCl}$, $1 \mathrm{~mm}$ EDTA, 0.1\% sarkosyl, $\mathrm{pH} 7.6$, in a Spinco SW27 rotor at $23,000 \mathrm{rpm}$ at $10^{\circ} \mathrm{C}$ for $16 \mathrm{~h}$.
Restriction endonucleases. EndoR PstI was isolated as described by Smith et al. (1976). EndoR ·HaeIII and endoR·HindII were gifts of Dr. P. D. Baas, Utrecht. EndoR $\cdot E c o R I$ was a gift of Dr. J. Sussenbach, Utrecht. EndoR-BamHI was purchased from New England, Biolabs, Beverly, Mass.

Cleavage of plasmid DNA by restriction endonucleases. Plasmid DNA (1.0 to $2.0 \mu \mathrm{g}$ ) was incubated with the amount of restriction endonuclease appropriate to achieve a complete digestion in $2 \mathrm{~h}$. The reaction volume was $0.04 \mathrm{ml}$. The reaction conditions for the different enzymes were: $10 \mathrm{~mm}$ Tris $-\mathrm{HCl}$, pH 7.6, $7 \mathrm{~mm} \mathrm{MgCl}_{2}, 7 \mathrm{~mm}$ mercaptoethanol, at $30^{\circ} \mathrm{C}$ for endoR $P s t \mathrm{I}$ and at $37^{\circ} \mathrm{C}$ for

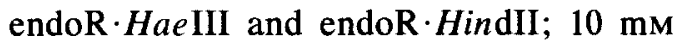
Tris- $\mathrm{HCl}$, pH 7.6, and $25 \mathrm{mM} \mathrm{MgCl}_{2}$ at $37^{\circ} \mathrm{C}$ for endoR $\cdot E c o R I$; and $10 \mathrm{~mm}$ Tris $-\mathrm{HCl}$, $\mathrm{pH} 7.6,7 \mathrm{~mm} \mathrm{MgCl}_{2}, 7 \mathrm{~mm}$ mercaptoethanol, $150 \mathrm{~mm} \mathrm{NaCl}, 0.01 \% \mathrm{BSA}$ at $37^{\circ} \mathrm{C}$ for endoR·Bam $\mathrm{HI}$.

Gel electrophoresis of DNA. Electrophoresis of plasmid DNA was performed on horizontal slab gels of $0.6 \%$ agarose ( $3 \mathrm{~mm}$ thick, $19 \mathrm{~cm}$ wide, and $19 \mathrm{~cm}$ long). Ethidium bromide was present both in the gel and in the electrophoresis buffer at a concentration of $2 \mu \mathrm{g} / \mathrm{ml}$. The electrophoresis buffer was $0.04 \mathrm{M}$ Tris, $0.01 \mathrm{M}$ sodium acetate, $0.001 \mathrm{M}$ EDTA, pH 7.8. The gels were run at $150-200 \mathrm{~V}$ for $2-6 \mathrm{~h}$. Photographs of the gels were made under long wave ultraviolet light.

To calculate the molecular weights of the plasmid DNAs, preparations of different standard reference DNAs were run on the same gel. These standard reference DNAs were the plasmids isolated from strain M46 ( $E$. coli $\mathrm{W} 3110 \mathrm{~N}$ carrying three independent plasmids derived from Salmonella panama) with molecular weights of $2.7 \times 10^{6}, 9.3$ $\times 10^{6}$, and $20.6 \times 10^{6}$ (Van Embden et al., 1976) obtained from Dr. J. D. A. van Embden, the CCC double-stranded (DS) DNAs of bacteriophages M13, $\phi \times 174$, and PM2 with molecular weights of $4.0 \times 10^{6}, 3.54$ $\times 10^{6}$, and $6.3 \times 10^{6}$, respectively (Brack 
et al., 1975; Van den Hondel and Schoenmakers, 1976; Sanger et al., 1977), and the plasmids isolated from Synechococcus strain 7002 with molecular weights of 3.0 $\times 10^{6}, 6.5 \times 10^{6}, 10.3 \times 10^{6}, 20.1 \times 10^{6}$, $24.7 \times 10^{6}$, and $75 \times 10^{6}$ (Roberts and Koths, 1976).

Analyses of restriction endonuclease digests of plasmid DNA were carried out by electrophoresis either on horizontal $2 \%$ agarose slab gels as described above or on discontinuous polyacrylamide slab gels as described previously (Van den Hondel and Schoenmakers, 1976).

Heat treatment of plasmid DNA. To determine whether the DNA bands on the agarose gels contain CCC DS DNA, 50- $\mu 1$ samples of DNA in TE buffer containing $0.1 \%$ Sarkosyl were heated for $2 \mathrm{~min}$ at $100^{\circ} \mathrm{C}$ followed by cooling in ice-water, and immediately applied to the gel in order to start the electrophoresis before renaturation takes place. The CCC DS and singlestranded (SS) DNAs from the bacteriophages M13 and $\phi$ X174 (Van den Hondel $e t$ al., 1975; Weisbeek et al., 1976) were heat treated in the same way.

Electron microscopy. Plasmid DNA was spread for electron microscopy by the formamide modifications of a protein monolayer technique (Davis et al., 1971). The spreading conditions used were: $0.5 \mu \mathrm{g}$ plasmid $\mathrm{DNA} / \mathrm{ml}, 0.2 \mu \mathrm{g}$ open circular (OC) DS $\phi \mathrm{X} 174 \mathrm{DNA} / \mathrm{ml}, 50 \%(\mathrm{v} / \mathrm{v})$ formamide, 0.1 $\mathrm{M}$ ammonium acetate, $\mathrm{pH}$ 8.0, $10 \mathrm{~mm}$ EDTA, and $0.02 \%(\mathrm{w} / \mathrm{v})$ cytochrome $c$. The subphase was triple-distilled water. The cytochrome $c$-nucleic acid film was picked up on carbon-coated copper grids. The specimens were stained with alcoholic uranyl acetate and rotary shadowed with platinum (Keegstra et al., 1977). The specimens were examined and photographed in a Philips EM 301 at different (film) magnifications. The magnification was calibrated on each film with a carbon grating replica (2160 lines per $\mathrm{mm}$ ). Length measurements were carried out with a Hewlett-Packard 9864A digitizer connected to a $9820 \mathrm{~A}$ calculator. The molecu- lar weights were calculated from the internal standard OC DS $\phi \times 174$ DNA [molecular weight $3.54 \times 10^{6}$ (Sanger et al., 1977)].

\section{RESULTS}

Analysis for the Presence of Plasmid DNA

A general method to analyze bacterial strains for the presence of covalently closed circular (CCC) plasmid DNA is the lysis of the bacterial cells, followed by an analysis of the cell content in $\mathrm{CsCl}$-ethidium bromide gradients. Since CCC DNA bands at a heavier position than relaxed chromosomal DNA (due to a restrictive uptake of ethidium bromide), the presence of two DNA bands in a $\mathrm{CsCl}$-ethidium bromide gradient indicates that the cells contain plasmid DNA. In this way six lysozyme-sensitive strains of unicellular cyanobacteria were tested, namely, Synechococcus strains 6301 (Anacystis nidulans), 6908 (Synechococcus cedrorum), 6312, 6707, 7425, and Synechocystis strain 7005 (Microcystis aeruginosa). $\mathrm{CsCl}$-ethidium bromide density gradient centrifugation of the PEG-concentrated clear lysates of cultures of each of these strains resulted in gradients with two DNA bands. The minor band present on the dense side of the major, chromosomal, DNA band indicates the presence of plasmid DNA in a CCC form. A similar result was found for Anacystis nidulans by Asato and Ginoza (1973) and Restaino and Frampton (1975). The DNA present in the minor band was analyzed both by agarose gel electrophoresis and electron microscopy, which confirmed the $\mathrm{CCC}$ conformation and revealed the number and the size of the different plasmid species.

\section{Plasmid Species}

To determine the number of the different plasmid species from the agarose gel patterns (Fig. 1), it was necessary to verify the CCC character of the DNA bands. Instead of the usual methods (Meyers et al., 1976; Van Embden et al., 1976) we have used another, based on the property of CCC DNA to main- 


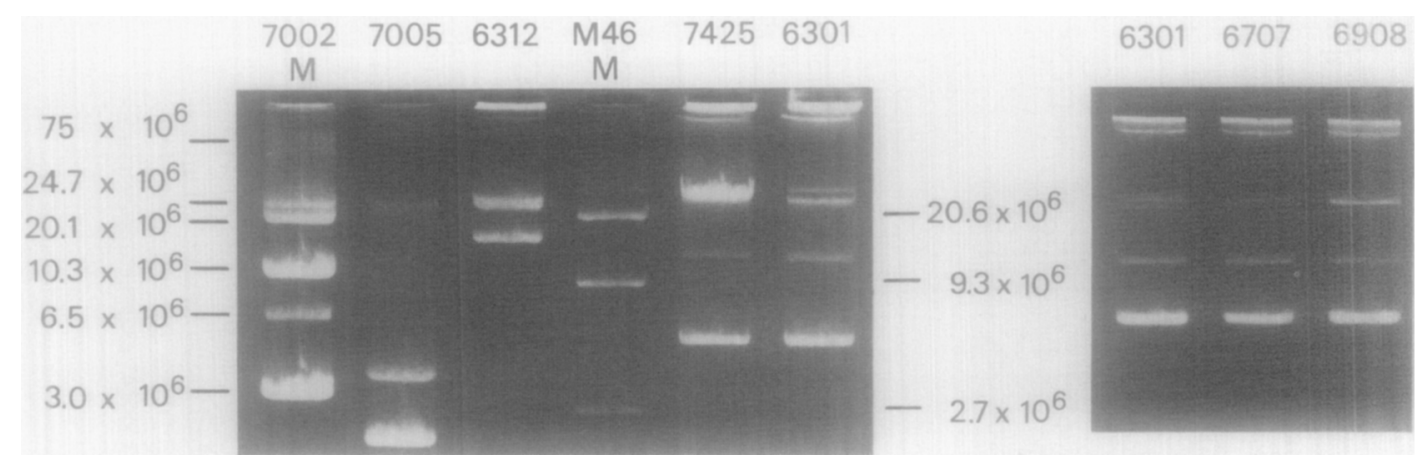

FIG. 1. Agarose gel electrophoresis of plasmid DNA isolated from the unicellular cyanobacterial strains Synechococcus 6301, 6312, 6707, 6908, and 7425 and Synechocystis 7005. The plasmid DNAs were purified by $\mathrm{CsCl}$-ethidium bromide centrifugation and analyzed by gel electrophoresis on a $0.6 \%$ horizontal agarose slab gel in the presence of $2 \mu \mathrm{g}$ ethidium bromide per $\mathrm{ml}$. Bands were visualized under ultraviolet light. Migration was from top (cathode) to bottom (anode). Marker plasmid DNA (M) from Synechococcus 7002 and $E$. coli M46 were run on the same gel and the molecular weights of the CCC form of these marker DNAs are indicated on the left and the right hand side of the gel, respectively.

tain its $\mathrm{CCC}$ character after heat treatment ( 2 min at $100^{\circ} \mathrm{C}$, followed by fast cooling), whereas open circular (OC) or linear DNA is converted into single-stranded (SS) DNA. Since SS DNA has a higher mobility than OC DNA, electrophoresis of heat-treated OC DNA will result in the simultaneous disappearance of an OC DNA band and appearance of a faster migrating SS DNA band. Electrophoresis of heat-treated CCC DNA will not lead to a change in the position of the DNA band.

To demonstrate the validity of this method we compared heat-treated $\mathrm{CCC}$ and $\mathrm{OC}$ DNA of the bacteriophages M13 and $\phi \times 174$ with unheated DNA on agarose gels. As shown in Fig. 2 the OC DNA band of M13 and $\phi \times 174$ disappears after heat treatment, whereas a new faster migrating band appears. This new band has the same mobility as SS DNA of M13 and $\phi \times 174$, indicating that it consists of SS DNA. As a control the OC and CCC DNA bands of unheated M13 and $\phi$ X174 DNA were checked for their OC and CCC character by alkaline sucrose gradient centrifugation (data not shown). It is clear from the gels that the CCC DNA band does not change its position after heat treatment.

With this method we analyzed the plasmid
DNA of the six cyanobacterial strains. The results are shown in Fig. 2. Each plasmid species should appear in one or two bands on the gel, in the unheated samples as CCC or CCC and OC DNA, in the heated samples as CCC or CCC and SS DNA, respectively. We found plasmid DNA of two discrete sizes in strains $6301,6707,6908$, and 7425 and of only one size in strains 6312 and 7005 .

It is interesting to note that the $\mathrm{OC}$ form of the larger plasmids of strains 6301,6707 , and 6908 (all with a molecular weight of 33 $\times 10^{6}$, see below) show a greater mobility than their corresponding $\mathrm{CCC}$ forms, whereas generally OC DNA migrates slower than CCC DNA. A combined analysis of these larger plasmids in neutral sucrose gradients and agarose gel electrophoresis showed that the DNA form with the higher $S$ value in the sucrose gradient migrates slower on the agarose gels and behaves like CCC DNA after heat treatment. A similar observation has been made by Van Embden et al. (1976) with a plasmid of MW $54 \times 10^{6}$ from Salmonella.

\section{Molecular Weights}

The molecular weight of the plasmids present in the six strains were determined 


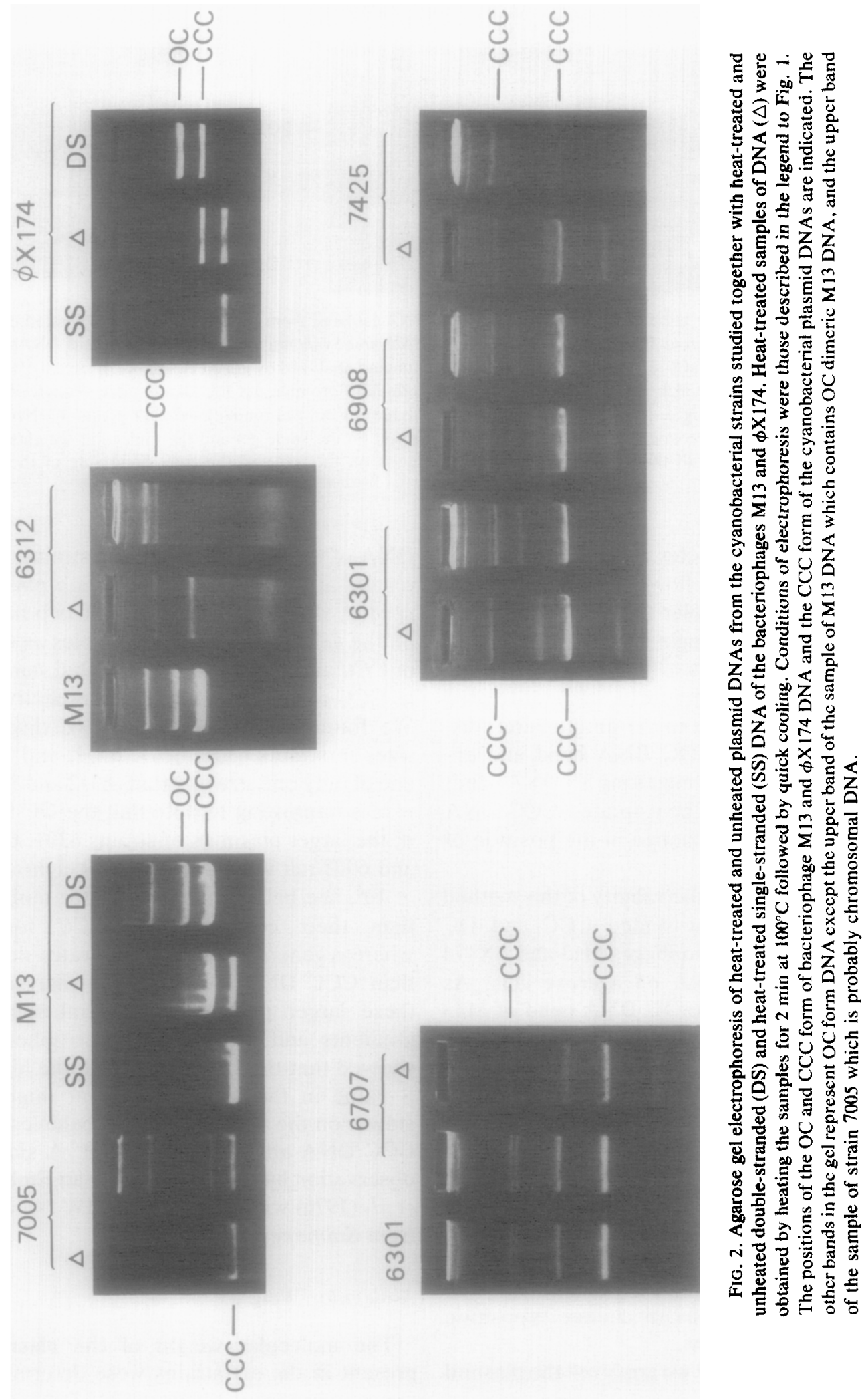


TABLE 1

Molecular Weight Determinations by Agarose Gel Electrophoresis and Contour Length Measurements of Plasmids from Six Unicellular Cyanobacteria

\begin{tabular}{|c|c|c|c|c|c|}
\hline \multirow[b]{2}{*}{ Strain } & \multirow[b]{2}{*}{$\begin{array}{c}\text { Plasmid } \\
\text { designation }\end{array}$} & \multicolumn{2}{|c|}{$\begin{array}{l}\text { Molecular weights from } \\
\text { contour length }\end{array}$} & \multicolumn{2}{|c|}{$\begin{array}{l}\text { Molecular weights from } \\
\text { gel electrophoresis }\end{array}$} \\
\hline & & $\begin{array}{l}\text { Number of } \\
\text { molecules } \\
\text { measured }\end{array}$ & $\begin{array}{c}\mathrm{MW}^{a} \\
\left(\times 10^{6}\right)\end{array}$ & $\begin{array}{c}\text { Number of } \\
\text { determinations }\end{array}$ & $\underset{\left(\times 10^{6}\right)}{\mathrm{MW}}$ \\
\hline \multirow[t]{2}{*}{6301} & pUH1 & 35 & $5.28 \pm 0.24$ & 3 & $5.1-5.4$ \\
\hline & pUH2 & 35 & $32.7 \pm 1.3$ & 3 & $32-34$ \\
\hline \multirow[t]{2}{*}{6707} & pUH3 & & n.d. ${ }^{b}$ & 3 & $5.1-5.4$ \\
\hline & pUH4 & & n.d. & 3 & $32-34$ \\
\hline \multirow[t]{2}{*}{6908} & pUH5 & 36 & $5.31 \pm 0.17$ & 3 & $5.1-5.4$ \\
\hline & pUH6 & 25 & $32.4 \pm 1.2$ & 3 & $32-34$ \\
\hline \multirow[t]{2}{*}{7425} & pUH7 & 76 & $5.43 \pm 0.22$ & 3 & $5.2-5.5$ \\
\hline & pUH8 & 17 & $23.7 \pm 0.9$ & 3 & $23-25$ \\
\hline 6312 & pUH9 & 24 & $15.9 \pm 0.5$ & 3 & $15.5-16.5$ \\
\hline 7005 & pUH 10 & 78 & $2.01 \pm 0.05$ & 3 & $1.9-2.1$ \\
\hline
\end{tabular}

a Molecular weights were calculated from OC DS $\phi$ X174 DNA (molecular weight $3.5 \times 10^{6}$ ) as an internal standard.

${ }^{b}$ n.d., not determined.

by agarose gel electrophoresis of the plasmid DNAs together with marker CCC DNAs of known molecular weight. Since the mobility of CCC DNA is proportional to the logarithm of its molecular weight in the range of 0.6 $\times 10^{6}$ to $95 \times 10^{6}$ (Meyers et al., 1976), the molecular weights of the various cyanobacterial CCC DNA species were calculated from the plot of the logarithms of the molecular weights of the marker CCC DNAs against their position on the gel (Table 1).

The plasmid DNA samples were also analyzed in the electron microscope. The same number of plasmid species per cyanobacterial strain was found as indicated by the agarose gels. The molecular weights, as calculated from the contour lengths (Table 1), were in good agreement with those determined from the electrophoretic mobilities.

\section{Homology of Plasmids from Various Strains}

Since the plasmid species present in 6301 , 6707 , and 6908 were similar in size, we considered the possibility that they are related. One test of relationship is to compare their restriction enzyme fragment patterns (Thompson et al., 1974). Therefore the two plasmid species from 6301,6707 , and 6908 were separated by sucrose centrifugation, digested separately with various restriction endonucleases and analyzed on gels.

Digestion with the restriction enzymes endoR.HindII and endoR.Hae III yielded identical fragment patterns for the $5.3 \times 10^{6}$ plasmids pUH1, pUH3, and pUH5, and for the $33 \times 10^{6}$ plasmids pUH2, pUH4, and pUH6 (Figs. 3 and 4). Indistinguishable patterns were also observed after digestion with the restriction endonucleases endoR. EcoRI, endoR $\cdot B a m \mathrm{HI}$, and endoR.Pst $\mathrm{I}$ (results not shown). The number of fragments produced by each enzyme are given in Table 2. The results indicate that the plasmid species with corresponding sizes present in the strains 6301, 6707, and 6908 contain very homologous DNA sequences. A further biochemical study is needed, however, to determine whether these plasmids are identical.

Analysis of the $5.4 \times 10^{6}$ plasmid pU7 from 7425 with the restriction enzymes endoR·HindII and endoR·HaeIII revealed 


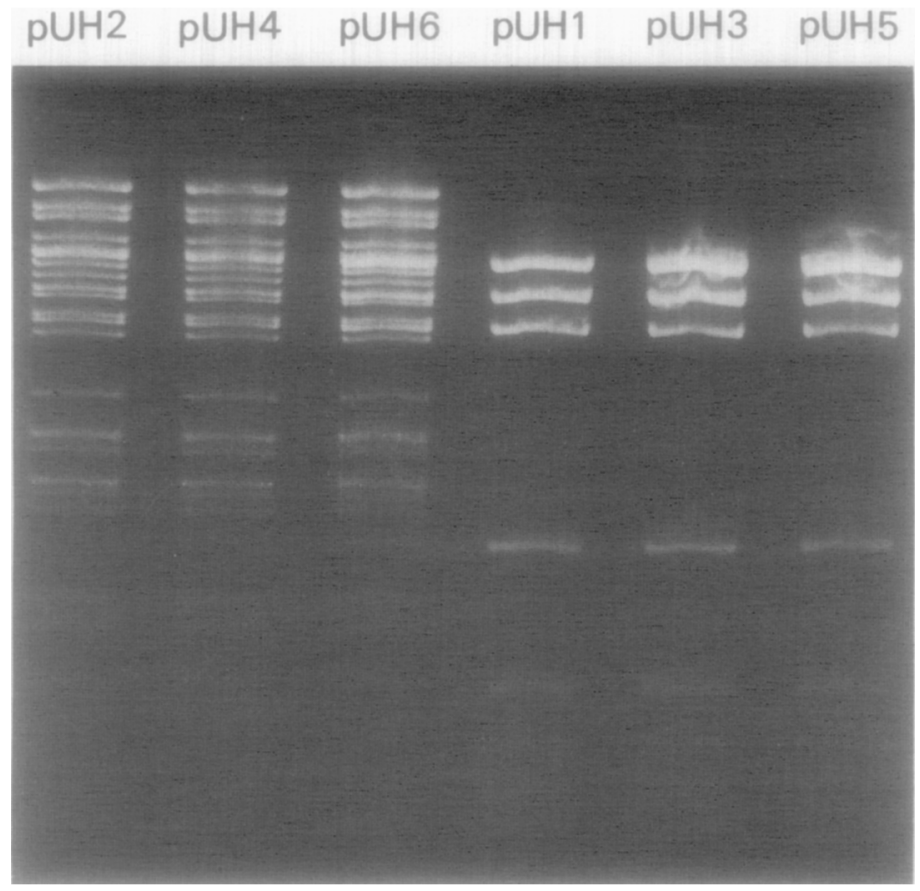

FIG. 3. Cleavage patterns of the plasmids pUH1 through pUH6 after digestion with endoR H HindII. DNA samples $(1$ to $2 \mu \mathrm{g}$ ) were treated with endoR $\cdot$ HindII for $2 \mathrm{~h}$ prior to stopping with EDTA. The reaction mixtures were analyzed on a horizontal $2 \%$ agarose slab gel.
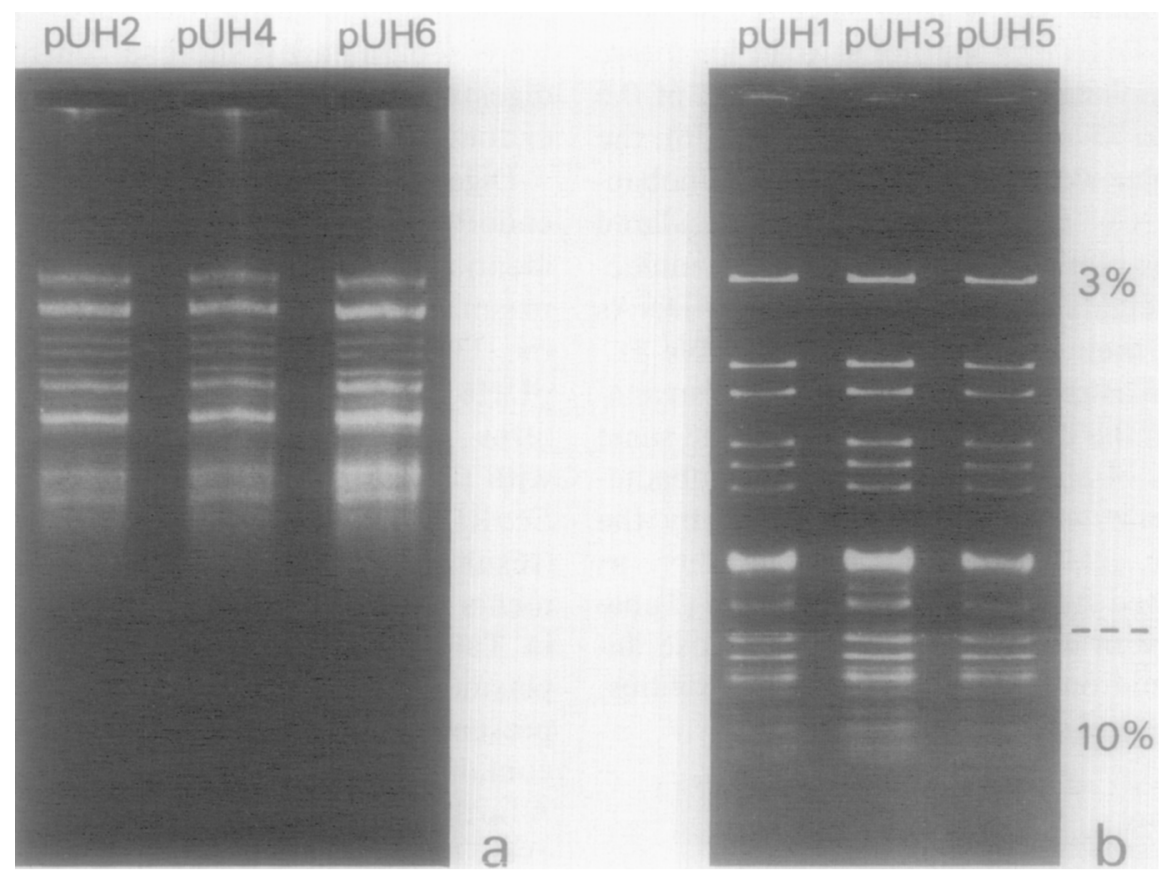

FIG. 4. Cleavage patterns of the plasmids pUH1 through pUH6 with endoR $\cdot$ HaeIII. Digests were fractionated by gel electrophoresis (a) on a horizontal $2 \%$ agarose gel, (b) on a discontinuous polyacrylamide slab gel, consisting of a $3 \%$ polyacrylamide gel on top of a $10 \%$ polyacrylamide gel layer. DNA samples ( 1 to $2 \mu \mathrm{g}$ ) were treated with endoR $\cdot H a e$ III for 2 h prior to stopping with EDTA. 
restriction patterns which are different from the patterns of the $5.3 \times 10^{6}$ plasmids pUH1, pUH3, and pUH5 (results not shown), suggesting that $\mathrm{pUH} 7$ is not related to these plasmids.

\section{Check on Bacterial Contaminants}

To exclude the possibility of contamination both the stock cultures and the 4-liter cultures were checked routinely for the presence of any bacterial contaminant in the following way. A sample of the cultures was (i) spread on agar-solidified bacterial growth medium supplemented with casamino acids $(0.5 \mathrm{~g} /$ liter) and sucrose $(0.5 \mathrm{~g} / \mathrm{liter})$ and incubated under conditions that enable only bacteria to grow (in the dark), (ii) subjected to Gram staining (cyanobacteria are Gramnegative) as a control on the uniformity of the culture, (iii) transferred to standard liquid medium and to the same medium supplemented with casamino acids $(0.5 \mathrm{~g} /$ liter $)$ and glucose $(0.5 \mathrm{~g} /$ liter $)$, incubated for 1 week, and monitored for contamination by microscopic examination, and (iv) examined in thin section in the electron microscope for the presence of cells without thylakoid membranes. If these checks gave no indication of contamination, we concluded that the isolated plasmid(s) originated from the cyanobacterial strain under study.

\section{DISCUSSION}

The results described in this paper reveal that the unicellular cyanobacterial strains Synechococcus 6301, 6312, 6707, 6908, 7425, and Synechocystis 7005 contain plasmid DNA of sizes ranging in molecular weight from $2 \times 10^{6}$ to $33 \times 10^{6}$. All the plasmids were isolated under rigorous lysis conditions. It may be possible that under these conditions very large plasmid species remain unnoticed. Therefore, we tested our lysis procedure on Synechococcus strain 7002, from which Roberts and Koths (1976) isolated several plasmid species, the largest having a molecular weight of $75 \times 10^{6}$. We were able to isolate the same number of

\section{TABLE 2}

Number of Fragments after Digestion of THE Plasmids pUH1 THROUGH pUH6 BY VARIOUS ENDONUCLEASES

\begin{tabular}{lcccccc}
\hline & pUH1 & pUH3 & pUH5 & pUH2 & pUH4 & pUH6 \\
\hline Eco RI & 0 & 0 & 0 & 9 & 9 & 9 \\
BamHI & 1 & 1 & 1 & 7 & 7 & 7 \\
PstI & 8 & 8 & 8 & $18^{a}$ & $18^{a}$ & $18^{a}$ \\
HindII & 8 & 8 & 8 & $25^{a}$ & $25^{a}$ & $25^{a}$ \\
Hae HI & $22^{a}$ & $22^{a}$ & $22^{a}$ & $>36^{a}$ & $>36^{a}$ & $>36^{a}$ \\
\hline
\end{tabular}

a Determination of the exact number of DNA fragments becomes inaccurate in the case of a high number of restriction enzyme cleavage sites. In these cases only a minimal estimate of the number of fragments is given.

plasmid species, thus our lysis procedure is suitable for the isolation of plasmids up to a molecular weight of at least $75 \times 10^{6}$.

Three of the strains contain plasmids of similar sizes, (Table 1), namely, the plasmids of $5.3 \times 10^{6}$ and $33 \times 10^{6} \mathrm{MW}$ in strains 6301,6707 , and 6908. Analysis of these plasmids with five different restriction endonucleases reveal identical cleavage patterns for the $5.3 \times 10^{6}$ plasmids pUH1, pUH3, and pUH5, and for the $33 \times 10^{6}$ plasmids pUH2, pUH4, and pUH6. Since similar cleavage patterns are strong indications of DNA sequence homologies (Thompson et al., 1974), these results suggest that the strains 6301,6707 , and 6908 carry homologous plasmid species, though these strains are different in size and base composition of their genomes (Herdmann et al., 1978). This may be an indication that a mechanism for the transfer of plasmids exists between these three strains. A similar relationship has been shown between plasmids of different $\mathrm{Hae}$ mophilus influenzae strains (Elwell et al., 1977), Thermus flavus strains (Hishinuma et al., 1978), Pseudomonas puta strains (Duggleby et al., 1977), and Streptomyces coelicolor strains (Schrempf and Goebel, 1977).

It is worth noting that the plasmids pUH1, pUH3, and pUH5, contain one cleavage site for the restriction enzyme endoR-Bam HI. This enzyme produces cohesive ends, which is helpful for the preparation of recombinant DNA in vitro (Roberts, 1976). This property 
together with the relatively small size of these plasmids may facilitate molecular genetics in some of the unicellular cyanobacteria.

At the moment nothing is known about the function of the plasmids found in the different cyanobacterial strains. It is reasonable to assume that these plasmids have functions comparable to those of plasmids in other bacterial strains, e.g., resistance to heavy metals and drugs, sexuality, biodegradation of aromatic compounds, and bacteriocin production (for a list of functions, see Novick et al., 1976). At the moment we are testing for toxin production and resistance to heavy metals and antibiotics.

Another function that often has been postulated for plasmids in cyanobacteria and other photosynthetic bacteria is involvement in photosynthesis (Asato and Ginoza, 1973; Gibson and Niederman, 1970; Roberts and Koths, 1976; Saunders et al., 1976). However, we could find no plasmids in Synechococcus strain 6715 , so the presence of plasmids may not be an absolute requirement for photosynthesis in cyanobacteria. On the other hand the possibility cannot be excluded that some plasmids provide additional photosynthetic properties, for instance the ability to function better under difficult photosynthetic conditions such as high light intensities. Elimination of plasmids from the cyanobacteria with the aid of a curing agent may give information on this matter.

\section{ACKNOWLEDGMENTS}

The authors wish to thank Dr. R. Y. Stanier, Dr. N. G. Carr, Dr. R. Safferman, and Miss Rosemarie Rippka for their generous gifts of cyanobacterial strains, Dr. J. D. A. van Embden for his gift of M46 plasmid DNA, and Dr. P. D. Baas and Dr. J. Sussenbach for their gifts of restriction enzymes. Thanks are also due to Dr. W. A. M. Linnemans for carrying out the electron microscopic checks of the cyanobacterial strains, and Miss Corrie van der Weele and Mr. Martin Post for numerous isolations of plasmid DNA.

\section{REFERENCES}

Asato, Y., And GinozA, H. S. (1973). Separation of small circular DNA molecules from the blue-green alga Anacystis nidulans. Nature New Biol. 244, 132-133.

Brack, C. B., Bickle, T. A., ANd YuAn, R. (1975). The relevation of single-standard regions in bacteriophage PM2 supercoiled DNA to the early melting sequences. J. Mol. Biol. 96, 693-702.

Carr, N. G., and Whitton, B. A. (1973). "The Biology of Blue-Green Algae." Botanical Monographs 9, Univ. of California Press, Berkeley and Los Angeles.

Davis, R. W., Simon, M., And Davidson, N. (1971). In "Methods in Enzymology" (L. Grossman and K. Moldave, eds.), Vol. 21, pp. 413-428. Academic Press, New York.

Dickerson, R. E., Timkovich, R., and Almassay, R. J. (1976). The cytochrome fold and evolution of bacterial energy metabolism. J. Mol. Biol. 100, 473493.

Duggleby, C. J., Bayley, S. A., Wasey, M. J., Williams, P. A., AND BRodA, P. (1977). Molecular sizes and relationship of Tol plasmids in Pseudomonas. I. Bacteriol. 130, 1274-1280.

Elwell, L. P., Saunders, J. R., Richmond, M. H., AND FALKOW, S. (1977). Relationship among some $\mathbf{R}$ plasmids found in Haemophilus influenzae. $J$. Bacteriol. 131, 356-362.

Fogg, G. E., Stewart, W. D. P., FAy, P., and Walsby, A. E. (1973). "The Blue-Green Algae." Academic Press, London and New York.

Gibson, K. D., ANd Niederman, R. A. (1970). Characterization of two circular satelite species of deoxyribonucleic acid in Rhodopseudomonas spheroides. Arch. Biophys. 141, 694-704.

Guerry, P., LeBlanc, D. J., And Falkow, S. (1973). General method for the isolation of plasmid deoxyribonucleic acid. J. Bacteriol. 116, 1064-1066.

HerdmanN, M. (1976). The cvolution of cyanobacterial genomes. Abstr. 2nd Int. Symp. Photosynthetic Prokaryotes, August 1976, pp. 229-231. University of Dundee, Scotland.

Herdmann, M., Janvier, M., RipPKa, R., AND STANIER, R. Y. (1978). Genome size of cyanobacteria. Submitted for publication.

Herdmann, M., Janvier, M., Waterbury, J. B., RipPKa, R., AND Stanier, R. Y. (1978). Deoxyribonucleic acid base composition of cyanobacteria. Submitted for publication.

HerdmanN, M., and CarR, N. G. (1974). Estimation of the genome size of blue-green algae from DNA renaturation. Arch. Mikrobiol. 99, 251-254.

Hishinuma, F., Tanaka, T., and Sakaguchi, K. (1978). Isolation of extrachromosomal deoxyribonucleic acids from extremely thermophilic bacteria. $J$. Gen. Microbiol. 104, 193-199.

Humphreys, G. O., Willshaw, G. A., ANd ANderson, E. S. (1975). A simple method for the preparation of large quantities of pure plasmid DNA. Biochim. Biophys. Acta 383, 457-463.

Keegstra, W., VereiJken, J. M., and Jansz, H. S. 
(1977). Mapping and length measurements of restriction enzyme fragments by electron microscopy. Biochim. Biophys. Acta 475, 176-183.

MANn, N., ANd CARR, N. G. (1974). Control of macromolecular composition and cell division in the bluegreen alga Anacystis nidulans. J. Gen. Microbiol. 83, 399-405.

Meyers, J. A., Sanchez, D., Elwell, L. P., AND FALKow, S. (1976). Simple agarose gel electrophoresis method for the identification and characterization of plasmid deoxyribonucleic acid. J. Bacteriol. 127, 1529-1537.

Novick, R. P., Clowes, R. C., Cohen, S. N., Curtiss III, R., Datta, N., and Falkow, S. (1976). Uniform nomenclature for bacterial plasmids: A proposal. Bact. Rev. 40, 168-189.

Restaino, L., ANd Frampton, E. W. (1975). Labelling the deoxyribonucleic acid of Anacystis nidulans. J. Bacteriol. 124, 155-160.

Rippka, R., Nielson, A., Kunisawa, R., AND Cohen-BAzire, G. (1971). Nitrogen fixation by unicellular blue-green algae. Arch. Mikrobiol. 76, 341348.

RoBERTS, R. J. (1976). Restriction endonucleases. CRC Crit. Rev. Biochem. 5, 123-164.

Roberts, T. M., AND Koths, K. E. (1976). The bluegreen alga Agmenellum quadruplicatum contains covalently closed DNA circles. Cell 9, 551-557.

Roberts, T. M., Kotz, L. C., AND Loeblich III, A. R. (1977). Characterization of a blue-green algal genome. J. Mol. Biol. 110, 341-361.

Sanger, F., Air, G. M., Barrell, B. G., Brown, N. L., Coulson, A. R., Fiddes, J. C., Hutchison III, C. A., Slocombe, P. M., AN D SMIth, M. (1977). Nucleotide sequence of bacteriophage $\phi X 174$ DNA. Nature (London) 256, 687-695.

Saunders, V. A., Saunders, J. R., and Bemet, P. M. (1976). Extrachromosomal deoxyribonucleic acid in wild-type and photosynthetically incompetent strains of Rhodopseudomonas spheroides. J. Bacteriol. 125, 1180-1187.
SchrempF, H., ANd Goebel, W. (1977). Characterization of a plasmid from Streptomyces coelicolor A 3 (2). J. Bacteriol. 131, 251-258.

Smith, D. I., BlatTner, F. R., AND DAvies, J. (1976). The isolation and partial characterization of a new restriction endonuclease from Providentia stuartii. Nucleic Acids Res. 3, 343-353.

STANIER, R. Y. (1977). The position of cyanobacteria in the world of phototrophs. Carlsberg Res. Commun. 42, 77-98.

Stanier, R. Y., Kunisawa, R., Mandel, M., And Cohen-Bazire, G. (1971). Purification and properties of unicellular blue-green algae (Order Chroococcales). Bact. Rev. 35, 171-205.

Stewart, W. D. P. (1969). Biological and ecological aspects of nitrogen fixation by free-living microorganisms. Proc. Roy. Soc. B. 172, 367-388.

Thompson, R., Hughes, S. G., ANd Broda, P. (1974). Plasmid identification using specific endonucleases. Mol. Gen. Genet. 133, 141-149.

Van den Hondel, C. A., and Schoenmakers, J. G. G. (1976). Cleavage maps of the filamentous bacteriophages M13, fd, f1 and ZJ/2.J. Virol. 18, 10241039.

Van den Hondel, C. A., Weyers, A., Konings, R. N. H., ANd Schoenmakers, J. G. G. (1975). Studies on bacteriophage M13. II. The gene order of the M13 genome. Eur. J. Biochem. 53, 559-567.

Van Embden, J. D. A., Van Leeuwen, W. J., and GuinéE, P. A. M. (1976). Interference with propagation of typing bacteriophages by extrachromosomal elements in Salmonella typhimurium Bacteriophage type 505. J. Bacteriol. 127, 1414-1426.

Weisbeek, P. J., Vereijken, J. M., BaAs, P. D., Jansz, H. S., And Van Arkel, G. A. (1976). The genetic map of bacteriophage $\phi \times 174$ constructed with restriction enzyme fragments. Virology $\mathbf{7 2}$, 61-71.

Wolk, P. (1973). Physiology and cytological chemistry of blue-green algae. Bact. Rev. 37, 32-101. 